\title{
FORMY SKRÓCONE RZECZOWNIKÓW FRANCUSKICH OZNACZAJACYCH OSOBY
}

\begin{abstract}
A bstract. Gajos Mieczysław. Formy skrócone rzeczowników francuskich oznaczajacych osoby [Abbreviated forms of French nouns signifying persons]. Studia Romanica Posnaniensia, Adam Mickiewicz University Press, Poznań, vol. XXV/XXVI: 2000, pp. 89-96. ISBN 83-232-0965-0. ISSN 0137-2475.

The author of this article deals with the problems of "abbreviated forms" in French, emphasising the role which this type of lexical units performs in communication. Their detailed typology, mechanisms which are their foundation and their functioning in language are performed. In his conclusion the author postulates that this kind of lexical units should be taken into consideration more comprehensively than it has been so far.
\end{abstract}

\section{WSTEP}

Pewna grupa rzeczowników francuskich oznaczających osoby posiada formy skrócone, które są najczęściej używane w języku pisanym ze względów czysto ekonomicznych bądź zwyczajowych, na przykład: skróty imion autorów w przypisach bibliograficznych, tytuły przed nazwiskami, itp. Formy skrócone wyrazów oznaczających osoby nie sa jednak wyłącznie domeną języka pisanego. Również w potocznej francuszczyźnie mówionej możemy spotkać formy rzeczownikowe powstałe w wyniku słowotwórczych procedur redukcyjnych. $\mathrm{O}$ ile jednak skróty graficzne mają status form oficjalnych, notowanych przez slowniki języka francuskiego i są w pełni akceptowane w stylu urzędowym i standardowym, o tyle zredukowane formy rzeczowników występujące w języku mówionym są charakterystyczne dla stylu nieformalnego, często o zabarwieniu argotycznym. Należy jednak zauważyć, że niektóre z tych form uległy upowszechnieniu i są także odnotowywane we współczesnych słownikach języka francuskiego.

Celem niniejszego artykułu jest prezentacja i analiza form skróconych rzeczowników francuskich oznaczających osoby uwzględniająca słowotwórcze mechanizmy ich tworzenia. 


\section{MECHANIZMY TWORZENIA FORM SKRÓCONYCH RZECZOWNIKÓW OZNACZAJACYCH OSOBY}

Skracanie rzeczowników francuskich oznaczających osoby polega najczęściej na redukcji wyrazu lub grupy wyrazów do jednej lub kilku liter, po których lub pomiędzy którymi może występować kropka. Obecność kropki lub jej brak jest uzależniona od formy samego skrótu. Zgodnie z ogólną zasadą skracania wyrazów w języku francuskim, użycie kropki jest obowiązujące w tych formach skróconych, w których ostatnia użyta litera nie jest ostatnim grafem skracanej jednostki leksykalnej.

$\begin{array}{lll}\text { Monsieur } & > & M . \\ \text { Professeur } & > & \text { Prof. }\end{array}$

W przypadku, kiedy w formie skróconej występuje ostatnia litera wyrazu skracanego, kropki nie używa się:

$\begin{array}{lll}\text { Mademoiselle } & > & \text { Mlle } \\ \text { Monseigneur } & > & \text { Mgr }\end{array}$

Jak łatwo zauważyć na podstawie zaprezentowanych przykładów, forma skrócona jest drugą formą znaczącą tego samego elementu znaczonego. Możemy to zilustrować za pomoca poniższego schematu.

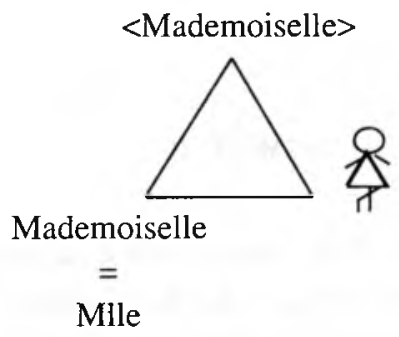

Analizując formy skrócone rzeczowników francuskich oznaczających osoby, wyodrębniliśmy kilka typów słowotwórczych, które prezentujemy poniżej.

\subsection{REDUKCJA GLOBALNA}

Redukcja globalna polega na skróceniu jednostki leksykalnej do jej grafemu inicjalnego, a w przypadku jednostki leksykalnej złożonej z dwóch lub więcej rzeczowników, do grafemów inicjalnych poszczególnych wyrazów tworzących daną syntagmę nominalną. Redukcja globalna wymaga użycia kropki.

Poniżej prezentujemy listę wybranych rzeczowników oznaczających osoby wraz $\mathrm{z}$ ich formami skróconymi, które zostały utworzone w wyniku redukcji globalnej. 


\begin{tabular}{|c|c|c|}
\hline Altesse & $>$ & A. \\
\hline Altesse Impériale & $>$ & A.I. \\
\hline Altesse Royale & $>$ & A.R. \\
\hline Femme & $>$ & $F^{*}$ \\
\hline Frère & $>$ & $F$ \\
\hline Homme & $>$ & $H{ }^{*}$ \\
\hline Jeune Homme & $>$ & J.H.* \\
\hline Jeune Femme & $>$ & $J . F{ }^{*}$ \\
\hline Jeune Fille & $>$ & $J . F *^{*}$ \\
\hline Monsieur & $>$ & $M$ \\
\hline Notre-Seigneur & $>$ & $N .-S$ \\
\hline Notre-Dame & $>$ & $N .-D$ \\
\hline Père & $>$ & $P$ \\
\hline Son Altesse & $>$ & S.A. \\
\hline Son Altesse Impériale & $>$ & S.A.I. \\
\hline Son Altesse Royale & $>$ & S.A.K \\
\hline Son Excellence & $>$ & S.E. \\
\hline Sa Grandeur & $>$ & $S . G$ \\
\hline Sa Majesté & $>$ & S.M. \\
\hline Sa Saintété & $>$ & S.S. \\
\hline
\end{tabular}

Formy skrócone powstałe w wyniku redukcji globalnej są notowane za pomocą dużych liter alfabetu.

Redukcja globalna bywa także stosowana w przypadku skracania większości imion.

$\begin{array}{lll}\text { André, Antoine, Anne } & > & A . \\ \text { Barbara, Boris } & > & B . \\ \text { Jean, Jacques, Julie } & > & J . \\ \text { Marc, Michel, Mireille } & > & M . \\ \text { Jean-Marc } & > & J .-M . \\ \text { Jean-Paul } & > & J .-P . \\ \text { Marie-Françoise } & > & M .-F .\end{array}$

itp.

W przypadku imion rozpoczynających się grafemem złożonym: Théodore, Philippe, Christine, itp. skrót uwzględnia oba grafy tworzące dany grafem, z tym jednak, że drugi element jest zapisywany małą litera:

$\begin{array}{lll}\text { Philippe } & > & P h . \\ \text { Thérèse } & > & T h . \\ \text { Chantal } & > & C h .\end{array}$

Uwaga! Jésus-Christ jest notowany w formie skróconej: J.-C.

* W skrótach prasowych obserwuje się formy bez kropki. 
Skróty powstałe w wyniku redukcji globalnej są wyłącznie skrótami graficznymi. Moga być realizowane fonicznie w trakcie lektury jedynie w ich pełnym brzmieniu.
M. [m $\phi s j \phi]$,
a nie $[\mathrm{em}]$
Ph. [filip],
a nie [pea], itd.

\subsection{REDUKCJA CZEŚCIOWA}

Redukcja częściowa polega na skróceniu jednostki leksykalnej poprzez usunięcie z niej pewnej liczby grafemów końcowych i pozostawieniu kilku początkowych liter wyrazu. Tak skrócony wyraz kończy się w zasadzie spółgłoska, po której stawiamy kropkę. Redukcja częściowa bywa często wykorzystywana przy skracaniu nazw zawodów i narodowości.

$\begin{array}{lll}\text { professeur } & > & \text { prof. } \\ \text { président } & > & \text { présid. } \\ \text { avocat } & > & \text { av. } \\ \text { ingénieur } & > & \text { ing. } \\ \text { directeur } & > & \text { dir. } \\ \text { psychologue } & > & \text { psych. } \\ \text { étudiant } & > & \text { étud. } \\ \text { Français } & > & \text { Franç. } \\ \text { Suédois } & > & \text { Suéd. } \\ \text { Américain } & > & \text { Am. } \\ \text { Espagnol } & > & \text { Esp. } \\ \text { Italien } & > & \text { It. }\end{array}$

Redukcja częściowa bywa czasami stosowana w skracaniu imion rozpoczynajacych się samogłoską: Antoine, Olivier, Yvonne, itp.

Skróty tego rodzaju imion możemy zapisywać jako:

An.

A.

Ol.

lub

$O$.

$Y v$.

$Y$.

Podobnie jak w przypadku redukcji globalnej, formy skrócone powstałe w wyniku redukcji częściowej są typowe dla języka pisanego. W trakcie lektury tekstów, w których występuja podobne skróty, należy je realizować fonicznie w brzmieniu rozwiniętych jednostek leksykalnych.

$\begin{array}{lll}\text { dir. } & > & {[\text { diRektoR }]} \\ \text { Yv. } & > & {[\text { ivon }]}\end{array}$

Zjawisko redukcji częściowej jest także obserwowane w procesie tworzenia skróconych form jednostek wyrazowych w języku mówionym. Tendencja do skracania 
wyrazów w mowie charakteryzuje styl potoczny, w szczególności żargon uczniowski i studencki.

W języku mówionym występują w zasadzie dwa podstawowe typy redukcji częściowej: apokopa i afereza.

Apokopa polega na usunięciu $\mathrm{z}$ jednostki podstawowej jednej lub kilku końcowych sylab.

$\begin{array}{lll}\text { l'archi(tec-te) } & > & \text { l'archi } \\ \text { le doc(teur) } & > & \text { le doc } \\ \text { le procu(reur) } & > & \text { le procu } \\ \text { le psy(cho-lo-gue) } & > & \text { le psy } \\ \text { le Yougo(sla-ve) } & > & \text { le Yougo }\end{array}$

W przypadku rzeczowników oznaczających osoby, wyraz skrócony kończy się często spółgłoską należącą do zredukowanej sylaby.

$\begin{array}{lll}\text { l'insti }+t \text {-u-t(eur }) & > & \text { l'instit } \\ \text { le pro }+f(\text { es-seur }) & > & \text { le prof } \\ \text { le ja }+p(o-\text {-nis }) & > & \text { le jap }\end{array}$

Wśród skróconych form rzeczowników francuskich oznaczających osoby, które powstały w wyniku apokopy istnieje pewna grupa wyrazów utworzonych w wyniku redukcji ostatniej sylaby i resufiksacji. Najczęściej dodawanymi formantami sa przyrostki: - o, -ot, $-d u,-a r d,-l o$, charakterystyczne dla francuskiego argot.

$\begin{array}{lcl}\text { le métall }(\text { ur-giste })+o & > & \text { le métallo } \\ \text { le music(ien })+o & > & \text { le musico } \\ \text { le pharmac(ien })+o & > & \text { le pharmaco } \\ \text { le Port }(u-\text {-gais })+o & > & \text { le Porto } \\ \text { le cuis }(i-\text {-nier })+t+\text { ot } & > & \text { le cuistot } \\ \text { le chôme }(\text { ur })+d u & > & \text { le chômedu } \\ \text { le plomb }(\text { ier })+\text { ard } & > & \text { le plombard } \\ \text { le pomp }(\text { ier })+l+\text { ard } & > & \text { le pomplard } \\ \text { le dir }(\text { ec-teur })+l o & > & \text { le dirlo } \\ \text { l'Amér }(i-\text {-cain })+l o & > & \text { l'Amérlo } \\ \text { le Pol(o-nais })+a(c) k & > & \text { le Polack } \\ \text { itp. } & & \end{array}$

Afereza polega na zredukowaniu jednej lub kilku sylab na początku wyrazu:
$l^{\prime}(A-m e ́)$-ricain
$>\quad$ le ricain
le (ca-)-pitaine
$>$ le pitaine
le (mar)-chand
$>$ le chand

W zapisie graficznym form skróconych powstałych w wyniku apokopy lub aferezy nie stawiamy kropki. 


\subsection{REDUKCJA TYPU: PIERWSZY I OSTATNI GRAFEM WYRAZU}

Kolejnym typem słowotwórczej redukcji wyrazowej jest skrót polegający na pozostawieniu pierwszego i ostatniego grafemu danej jednostki leksykalnej. W formach skróconych tego typu odrzucamy wszystkie grafemy znajdujące się pomiędzy grafemem inicjalnym i końcowym.

$\begin{array}{lll}D \text { (octeu)r } & > & \mathrm{Dr} \\ M(\text { aittr)e } & > & \mathrm{Me} \\ \text { M(ada)me } & > & \text { Mme } \\ \text { M(ademoise)lle } & > & \text { Mlle }\end{array}$

Skróty te piszemy bez kropki i realizujemy fonicznie jako pełne wyrazy.

Czasami możemy spotkać skrót: $M r$ od wyrazu $M$ (onsieu)r. Jego użycie wymaga pewnego wyjaśnienia. W zasadzie jedyną poprawną formą skróconą wyrazu Monsieur jest $M$. Wyjatkowo wyraz ten możemy zapisać za pomoca skrótu $M r$ lub $M^{r} \mathrm{z}$ literą $r$ w superskrypcie, jeżeli użycie samego $M$. powodowałoby niejasność komunikatu. Na przykład:

M. Mauger mogłoby być odczytane jako: Monsieur Mauger lub: Maurice Mauger.

W pierwszym przypadku należałoby użyć skrótu $M^{r}$. Jego użycie byłoby tym bardziej uzasadnione w przypadku zapisu: $M^{r} M$. Mauger.

\subsection{REDUKCJA TYPU: PIERWSZY + ŚRODKOWY + OSTATNI GRAFEM WYRAZU}

Ostatnim typem słowotwórczej redukcji wyrazowej spotykanym przy skracaniu wyrazów francuskich oznaczających osoby jest redukcja, w której pozostawiamy pierwszy, środkowy i ostatni grafem skracanej jednostki leksykalnej.

$$
\text { M(onsei)g(neu)r }>\quad M g r
$$

Skróty tego typu piszemy bez kropki i czytamy jako pełne wyrazy.

\section{RODZAJ I LICZBA MNOGA SKRÓCONYCH FORM RZECZOWNIKÓW OZNACZAJĄCYCH OSOBY}

Rodzaj gramatyczny skróconych form rzeczowników oznaczających osoby jest taki sam jak form pełnych:

$\begin{array}{ll}\text { un Américain } & >\text { un ricain } \\ \text { un psychologue } & >\text { un psy } \\ \text { une femme } & >\text { une } F . \\ \text { un homme } & >\text { un } H .\end{array}$


Nieco więcej uwagi wymaga zagadnienie tworzenia liczby mnogiej form skróconych rzeczowników oznaczających osoby. Właściwie każdy z zaprezentowanych w pierwszej części artykułu typów słowotwórczych tworzy liczbę mnogą w inny sposób.

Wyrazy powstałe w wyniku redukcji globalnej podwajaja w liczbie mnogiej grafemy inicjalne, do których zostały skrócone.

$\begin{array}{lll}M .(\text { Monsieur) } & > & M M . \text { (Messieurs) } \\ \text { A. }(\text { Altesse }) & > & A A . \text { Altesses) } \\ \text { F. (Frère) } & > & F F . \text { (Frères) } \\ P .(\text { Père) } & > & P P . \text { (Pères) } \\ \text { N.-S. (Notre-Seigneur) } & > & \text { NN.SS. (Nos Seigneurs) }\end{array}$

W formach złożonych, w których jeden z inicjałów jest skrótem zaimka przymiotnego dzierżawczego: son, sa: $S$., należy użyć w liczbie mnogiej skrótu $L L$. (leurs):

$\begin{array}{lll}\text { S.M. }(\text { Sa Majesté) } & > & \text { LL.MM. (Leurs Majestés) } \\ \text { S.M.R. (Sa Majesté Royale) } & > & \text { LL.MM.RR. (Leurs Majestés Royales) } \\ \text { S.E. (Son Excellence) } & > & \text { LL.EE. (Leurs Excellences) }\end{array}$

Skróty powstałe w wyniku redukcji częściowej, po których występuje kropka są niezmienne w liczbie mnogiej.

$\begin{array}{ll}\text { un édit.(eur) } & >\text { des édit.(eurs) } \\ \text { un Angl.(ais) } & >\text { des Angl.(ais) }\end{array}$

Jednostki leksykalne powstałe w wyniku apokopy i aferezy tworzą liczbę mnoga w sposób regularny, zgodnie z obowiązującymi zasadami tworzenia liczby mnogiej rzeczowników francuskich.

$\begin{array}{ll}\text { un instit } & >\text { des instits } \\ \text { un prof } & >\text { des profs } \\ \text { un musico } & >\text { des musicos } \\ \text { un sous-off } & >\text { des sous-offs } \\ \text { un ricain } & >\text { des ricains } \\ \text { un pitaine } & >\text { des pitaines }\end{array}$

Podobnie zachowują się skrócone formy wyrazów: madame, mademoiselle, matre, docteur, których skróty mają w liczbie mnogiej formę: $M^{\text {mes }}, M^{l l e s}, M^{e s}, D^{r s}$.

Wyjątek w tej serii wyrazów stanowi Monseigneur (Mgr) mający liczbę mnogą: NN.SS. (Nosseigneurs).

Ze względu na zasięg występowania form skróconych we współczesnej francuszczyźnie mówionej i pisanej, uważamy że zaprezentowane powyżej zagadnienie winno być w szerszym stopniu uwzględnione w materiałach glottodydaktycznych, zwłaszcza w podręcznikach gramatyki francuskiej adresowanych do studentów romanistyki i nauczycieli języka francuskiego jako obcego. 


\section{BIBLIOGRAFIA}

Béch ade H.D. (1994), Grammaire française, PUF, Paris.

B onnard H. (1993), Code du français courant, Ed. Magnard, Paris.

Doppagne A. (1991), Majuscules, abréviations, symboles et sigles. pour une toilette parfaite du texte, Duculot, Paris.

Fa u dou a s.C. (1990), Dictionnaire des abréviations courantes de la langue française, La Maison du dictionnaire, Paris.

Grevisse M. (1994), Le bon usage, refondu par A. Goosse, Ducluot, Paris.

Mitterand H. (1965), Les mots français, PUF, coll. Que sais-je?, Paris.

Poug o ois e M. (1996), Dictionnaire didactique de la langue franaise, Ar. Collin, Paris.

Riegel M. (1997), Grammaire méthodique du français, PUF, Paris. 